\title{
Exchangeable and Bioavailable Aluminium in the Mountain Forest Soil of Barania Góra Range (Silesian Beskids, Poland)
}

\author{
Maria Zołotajkin • Jerzy Ciba • Joanna Kluczka • \\ Monika Skwira • Adam Smoliński
}

Received: 12 April 2010 /Accepted: 8 July 2010 / Published online: 25 July 2010

(C) The Author(s) 2010. This article is published with open access at Springerlink.com

\begin{abstract}
The research was carried out in the spruce forests of Barania Góra (Silesian Beskids, Poland) affected by pandemic dying of trees. Twenty-seven samples were collected from the O layer in two plots: 17 in a cut down forest infested with insect pests (bark beetle) and ten in a 120-year-old healthy forest. The analyses covered basic parameters $\left(\mathrm{pH}_{\mathrm{H} 2 \mathrm{O}}\right.$, $\mathrm{pH}_{\mathrm{KCl}}, \mathrm{w}_{\text {org }}, \mathrm{C}_{\text {tot }}, \mathrm{N}_{\text {tot }}, \mathrm{CEC}$ ) and the concentrations of aluminium in the fractions leached with $0.1 \mathrm{M}$ $\mathrm{BaCl}_{2}\left(\mathrm{Al}_{\text {exch }}\right), 0.5 \mathrm{M} \mathrm{CuCl}_{2}$ and $0.1 \mathrm{M} \mathrm{Na}_{4} \mathrm{P}_{2} \mathrm{O}_{7}$ $\left(\mathrm{Al}_{\text {bio }}\right)$ solutions. The total aluminium concentration in the soil was assayed digesting samples with hydrofluoric acid. The effect of $\mathrm{pH}$ and organic matter content on the amount of exchangeable $\left(\mathrm{Al}_{\text {exch }}\right)$ and bioavailable $\left(\mathrm{Al}_{\text {exch }}\right)$ aluminium in the soil was analysed. It has been found that the soils in both plots are strongly acidic and contain 550 to $1,700 \mathrm{mg} \mathrm{kg}^{-1}$ of exchangeable aluminium and 1,200 to $4,800 \mathrm{mg} \mathrm{kg}^{-1}$ of bioavailable aluminium. The lack of disease symptoms in the spruce trees in plot 2 can
\end{abstract}

M. Zołotajkin $(\bowtie) \cdot J$. Ciba $\cdot$ J. Kluczka $\cdot$ M. Skwira

Faculty of Chemistry, Silesian University of Technology,

B. Krzywoustego Street 6,

44-100 Gliwice, Poland

e-mail: Maria.Zolotajkin@polsl.pl

A. Smoliński

Department of Energy Saving and Air Protection,

Central Mining Institute,

Plac Gwarków 1,

40-166 Katowice, Poland be explained by the higher content of organic matter in the soil. Unfortunately, one might expect that the high concentration of exchangeable aluminium will also cause the trees in the area to wither.

Keywords Forest soil · Mobile aluminium .

Speciation analysis

\section{Introduction}

Barania Góra (1,220 $\mathrm{m}$ above sea level) is the second highest mountain in the Silesian Beskids range, part of the Western Carpathians. It stretches mainly south and northward and is a watershed between the Vistula valley from the west and the Soła valley from the east. The rock body of its substantial part is composed of Godula sandstone and the massif itself is made up of Istebna sandstone. The climate in the Silesian Beskids is characterized by relatively heavy rainfalls (800$1,200 \mathrm{~mm} \mathrm{year}{ }^{-1}$ ) and snowfalls. The weather is under the influence of maritime polar air masses. The average annual temperature at the ridge reaches $5.4^{\circ} \mathrm{C}$. The climate is significantly affected by strong winds, and those blowing from the west and north-west predominate the peak parts of Barania Góra.

The area has been exposed to acid rain for years. Barania Góra lies adjacent to the Trzyniec smelting plant in the Czech Republic and is in close proximity to Katowice conurbation and large industrial plants, 
including coal-fired power stations (Rybnik Industrial Region in Poland and Ostrava and Karvina Region in the Czech Republic). It is also attractive in terms of tourism, which is the reason of the heavy traffic. The annual average concentrations of ions in the precipitation are as follows: $\mathrm{NO}_{3}=2.0-2.1 \mathrm{mgdm}^{-3}$ and $\mathrm{SO}_{4}=$ $3.45-4.21 \mathrm{mgdm}^{-3}$ (Staszewski 2004). The forests of Barania Góra are dominated by spruce monocultures started in the nineteenth century. Since the seeds were imported from the Alpine regions (others as well), the local and foreign spruce species intermingled.

Recently, the area of Barania Góra and the entire Silesian Beskids has been experiencing a deterioration in spruce stand. The youngest sprouts are turning yellow and shedding needles, crowns are getting thinner and in extreme cases, the trees wither. The area has been suffering an increasing plague of pests, e.g., bark beetle, armillaria and the like. In order to save healthy stands, large stretches of infested forest are cut down. Other parts of the world have experienced similar problems (USA, Canada, China, France, Germany, Scandinavia), including Poland - the Izera Mountains in the second half of the twentieth century and Opole Region in the 1990s.

Investigations into the pandemic dying of spruce forests are carried out in a number of countries. A series of works published by Czech researchers over 19992007 period (Borůvka et al. 2005a, b, c; Mládková et al. 2004, 2006; Musil and Pavliček 2002) was of special interest to us since they focused on the mountainous areas located in close proximity to the Żywiec and Silesian Beskids. In the Czech Republic, the degradation of spruce forest occurred in various regions of the country: the Jizerske Mountains, Beskids, Ore Mountains, Krusne Mountains. The authors point to the release of aluminium ions, toxic to coniferous trees in particular, as the main cause of forest degradation.

In Poland, the most extensive research in this field until now was carried out in the 1990s and covered the determination of different aluminium fractions in river and lake waters (Kotowski et al. 1994, 1995) and the soil solution itself (Smal and Misztal 1996). This work is aimed at assessing the quantity and forms of aluminium occurring in the soils of the Barania Góra range.

\section{Experimental}

The acidity of the soil in the area is caused primarily by anthropogenic factors the surface layer of the soil is particularly vulnerable to. The changes in the mineral layer are controlled mainly by the processes of soil formation (Borůvka et al. 2005a). Therefore, the soil samples were collected in the $O$ layers in spruce forests and mixed spruce-beech forests, spruce being predominant.
Fig. 1 Schematic of assays of selected aluminium forms in soil. Single asterisk refers to $v / m$ ratio between extractant volume $\left[\mathrm{cm}^{3}\right]$ and weight of air-dry soil sample [g]. Double asterisks represent extraction of three times for an hour, using a new portion of extractant each time

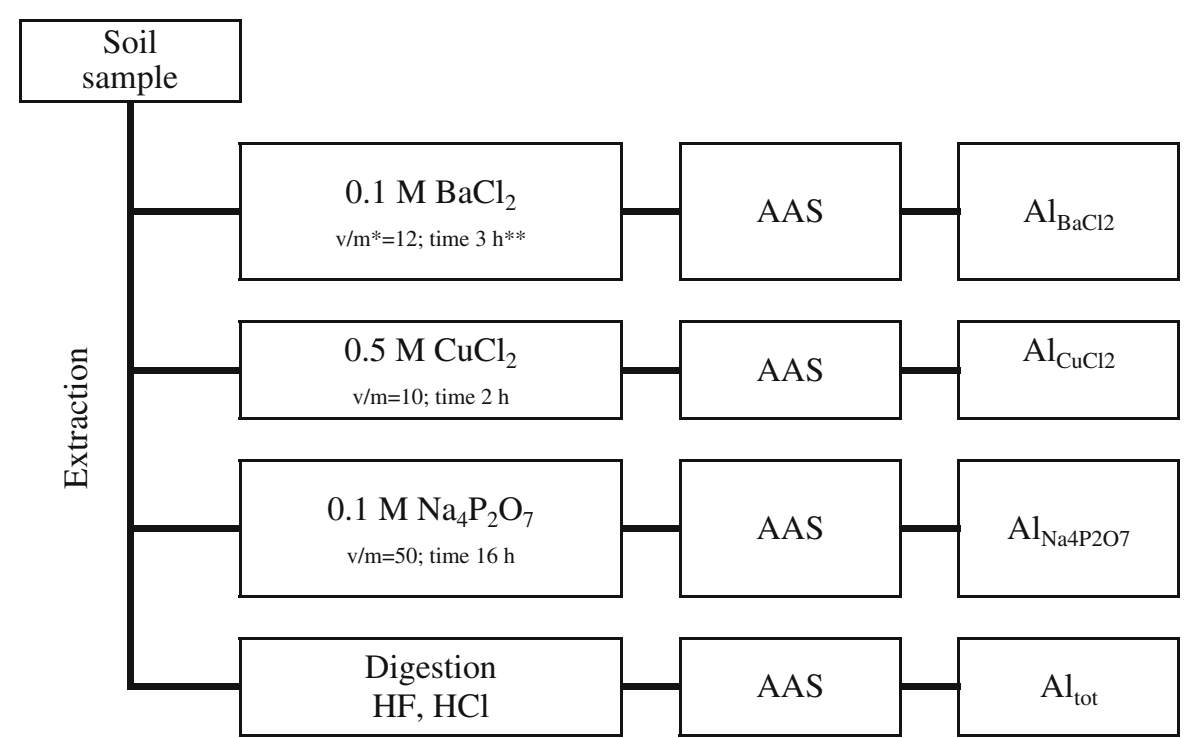

$*_{\mathrm{v}} / \mathrm{m}$ ratio between extractant volume $\left[\mathrm{cm}^{3}\right]$ and weight of air-dry soil sample $[\mathrm{g}]$ **extracted three times for an hour, using a new portion of extractant each time 
Table 1 Range, average and median of parameters measured in the soil of Barania Góra range

\begin{tabular}{|c|c|c|c|c|c|c|c|c|c|}
\hline \multirow[t]{2}{*}{ Parameter } & \multicolumn{4}{|l|}{ Istebna } & \multicolumn{4}{|l|}{ Bukowiec } & \multirow[t]{2}{*}{ SD } \\
\hline & Sample no. & Range & Average & Median & Sample no. & Range & Average & Median & \\
\hline $\mathrm{pH}_{\mathrm{H} 2 \mathrm{O}}$ & 17 & $3.39-3.91$ & 3.66 & 3.65 & 10 & $3.35-3.69$ & 3.57 & 3.59 & 0.02 \\
\hline $\mathrm{pH}_{\mathrm{KCl}}$ & & $2.79-3.39$ & 3.02 & 3.12 & & $2.57-2.91$ & 2.80 & 2.80 & 0.02 \\
\hline$w_{\text {org }}(\%)$ & & $11.9-63.4$ & 36.7 & 31.6 & & $17.4-84.8$ & 44.14 & 41.45 & 1 \\
\hline $\mathrm{C}_{\text {tot }}(\%)$ & & $5.02-32.4$ & 17.8 & 14.2 & & $9.71-44$ & 22.85 & 21.4 & 0.05 \\
\hline $\mathrm{N}_{\text {tot }}(\%)$ & & $0.18-1.46$ & 0.78 & 0.68 & & $0.32-1.32$ & 0.83 & 0.84 & 0.04 \\
\hline $\mathrm{CEC} \mathrm{cmol}_{\mathrm{c}}\left(\mathrm{kg}^{-1}\right)$ & & $9.48-22.41$ & 16.13 & 15.61 & & $9.67-20.71$ & 15.60 & 15.78 & 1.5 \\
\hline $\mathrm{Ca}_{\text {exch }}\left(\mathrm{mgkg}^{-1}\right)$ & 14 & $22-563$ & 161 & 110 & 9 & $28-703$ & 265 & 224 & \\
\hline $\operatorname{Mg}_{\text {exch }}\left(\mathrm{mgkg}^{-1}\right)$ & 17 & $13-140$ & 61 & 52 & 10 & $16-68$ & 40 & 38 & \\
\hline $\mathrm{K}_{\text {exch }}\left(\mathrm{mgkg}^{-1}\right)$ & & $37-251$ & 148 & 143 & & $70-193$ & 131 & 126 & \\
\hline $\mathrm{Fe}_{\text {exch }}\left(\mathrm{mgkg}^{-1}\right)$ & & $68-269$ & 144 & 128 & & $79-176$ & 112 & 102 & \\
\hline $\mathrm{Mn}_{\mathrm{exch}}\left(\mathrm{mg} \mathrm{kg}^{-1}\right)$ & & $2.69-28.84$ & 12.11 & 7.73 & & $0.87-33.2$ & 16.35 & 14.35 & \\
\hline $\mathrm{Ca}_{\text {tot }}\left(\mathrm{mgkg}^{-1}\right)$ & & $125-1,797$ & 581 & 337 & & $216-771$ & 527 & 536 & \\
\hline $\mathrm{Mg}_{\text {tot }}\left(\mathrm{mgkg}^{-1}\right)$ & & $949-5,840$ & 2,481 & 1,784 & & $513-1,330$ & 1,028 & 1,062 & \\
\hline $\mathrm{Al}_{\text {exch }}\left(\mathrm{mgkg}^{-1}\right)$ & & $639-1,716$ & 1,101 & 1,003 & & $548-1,062$ & 800 & 786 & 25 \\
\hline $\mathrm{Al}_{\mathrm{CuCl} 2}\left(\mathrm{mgkg}^{-1}\right)$ & & $893-1,969$ & 1,435 & 1,328 & & $868-1,711$ & 1,188 & 1,156 & 62 \\
\hline $\mathrm{Al}_{\mathrm{Na} 4 \mathrm{P} 2 \mathrm{O} 4}\left(\mathrm{Al}_{\text {bio }}, \mathrm{mgkg}^{-1}\right)$ & & $1,804-4,805$ & 2,731 & 2,359 & & $1,177-2,843$ & 1,782 & 1,734 & 93 \\
\hline $\mathrm{Al}_{\text {orgI }}\left(\mathrm{mgkg}^{-1}\right)$ & & $0-584$ & 338 & 402 & & $219-648$ & 360 & 388 & \\
\hline $\mathrm{Al}_{\text {org }}\left(\mathrm{mgkg}^{-1}\right)$ & & $846-3,342$ & 1,630 & 1,459 & & $528-1,781$ & 982 & 883 & \\
\hline $\mathrm{Al}_{\text {tot }},\left(\mathrm{gkg}^{-1}\right)$ & & $23.1-82.2$ & 50.4 & 44.8 & & $33.5-85.4$ & 23.2 & 24.4 & 0.5 \\
\hline Height(m) above sea level & & $690-850$ & & & & $645-720$ & & & \\
\hline
\end{tabular}

Overall, twenty-seven soil samples were collected. Seventeen were taken along the traverse of the mountain (Istebna Forest District), in the area of a cut down spruce forest infested with insect pests (bark beetles). Three soil samples were collected at the same height in a $300-\mathrm{m}$ strip of land (at 100-m intervals). The sampling height ranged from 690 to $850 \mathrm{~m}$. Ten samples were collected in a healthy 120-year-old spruce forest in the Bukowiec Forest District - also along the traverse of the mountain at $645-720 \mathrm{~m}$. Three reference samples were collected,
Fig. 2 Effect of $\mathrm{pH}_{\mathrm{H} 2 \mathrm{O}}$ and $\mathrm{pH}_{\mathrm{KCl}}$ on $\mathrm{Al}_{\text {exch }}$ concentrations in $\mathrm{O}$ layer
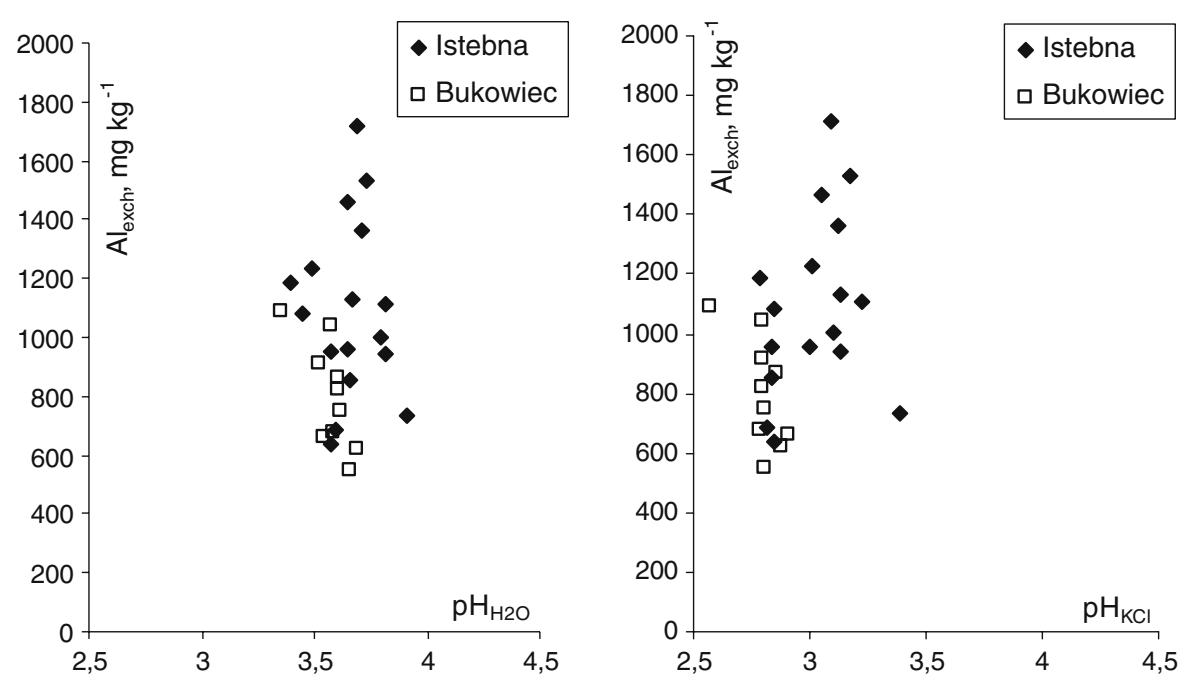
Table 2 Effect of $\mathrm{pH}$ on exchangeable aluminium concentration in soil (soil samples 1-5)

\begin{tabular}{|c|c|c|c|c|c|c|c|c|}
\hline \multirow[t]{2}{*}{ Soil sample no. } & \multicolumn{4}{|c|}{ Initial sample } & \multicolumn{4}{|c|}{ Samples after acidity change } \\
\hline & Level & $\mathrm{pH}_{\mathrm{H} 2 \mathrm{O}}$ & $\mathrm{pH}_{\mathrm{HCl}}$ & $w_{\text {org }}(\%)$ & $\mathrm{pH}_{\mathrm{H} 2 \mathrm{O}}$ range & $\mathrm{pH}_{\mathrm{KCl}}$ range & $\mathrm{Al}_{\text {exch }}\left(\mathrm{mgkg}^{-1}\right)$ & Number of samples \\
\hline 1 & Mineral & 5.08 & 4.38 & 1.00 & $3.28 \div 9.13$ & $3.52 \div 7.48$ & $1,248 \div 34$ & 6 \\
\hline 2 & Mineral & 4.69 & 4.09 & 3.64 & $3.40 \div 6.85$ & $3.56 \div 5.13$ & $684 \div 19$ & 5 \\
\hline 3 & Mineral & 6.04 & 4.06 & 5.60 & $1.86 \div 6.71$ & $2.00 \div 5.35$ & $1,020 \div 43$ & 9 \\
\hline 4 & Organic & 3.94 & 2.95 & 11.73 & $2.63 \div 7.92$ & $2.38 \div 5.74$ & $522 \div 31$ & 8 \\
\hline 5 & Organic & 4.01 & 2.93 & 38.20 & $2.49 \div 5.06$ & $2.60 \div 3.28$ & $1,349 \div 472$ & 9 \\
\hline
\end{tabular}

one in a 60-year-old spruce forest in Koszęcin and two in Sacdecki Beskid - a spruce enclave in a mixed forest at $750 \mathrm{~m}$.

Known techniques (Drábek et al. 2003; Ostrowska et al. 1991; Polish Standard PN-ISO 11260:1999) were used to determine: $\mathrm{pH}$ in water $\mathrm{pH}_{\mathrm{H} 20}$ and $1 \mathrm{M} \mathrm{KCl}$ solution $\mathrm{pH}_{\mathrm{KCl}}$; organic weight $w_{\mathrm{org}}[\% \mathrm{w}]$; total carbon $\mathrm{C}_{\text {tot }}\left[\begin{array}{ll}\% & \mathrm{w}]\end{array}\right.$ and total nitrogen $\mathrm{N}_{\text {tot }}\left[\begin{array}{ll}\% & \mathrm{w}\end{array}\right]$; cation exchange capacity $\mathrm{CEC}\left[\mathrm{cmol}_{\mathrm{c}} \mathrm{kg}^{-1}\right]$; contents of calcium $\mathrm{Ca}_{\text {exch }}\left[\mathrm{mgkg}^{-1}\right]$, magnesium $\mathrm{Mg}_{\text {exch }}[\mathrm{mg}$ $\left.\mathrm{kg}^{-1}\right]$, potassium $\mathrm{K}_{\text {exch }}\left[\mathrm{mgkg}^{-1}\right]$, iron $\mathrm{Fe}_{\text {exch }}\left[\mathrm{mgkg}^{-1}\right]$ and manganese $\mathrm{Mn}_{\text {exch }}\left[\mathrm{mgkg}^{-1}\right]$ in the exchangeable fraction; total content of calcium $\mathrm{Ca}_{\text {tot }}\left[\mathrm{mgkg}^{-1}\right]$ and magnesium $\mathrm{Mg}_{\text {tot }}\left[\mathrm{mgkg}^{-1}\right]$; aluminium in fractions leached with barium chloride $\mathrm{Al}_{\mathrm{BaCl} 2}\left[\mathrm{mgkg}^{-1}\right]$, copper chloride(II) $\mathrm{Al}_{\mathrm{CuCl} 2}\left[\mathrm{mgkg}^{-1}\right]$ and sodium pyrophosphate $\mathrm{Al}_{\mathrm{Na} 4 \mathrm{P} 207}\left[\mathrm{mgkg}^{-1}\right]$ and finally total aluminium $\mathrm{Al}_{\text {tot }}\left[\mathrm{mgkg}^{-1}\right]$ after the samples had been digested in hydrofluoric and hydrochloric acids.

The following aluminium forms described by (Drábek et al. 2003; Walna et al. 2005) were assumed: exchangeable $\left(\mathrm{Al}_{\text {exch }}\right)$, weakly organically bound $\left(\mathrm{Al} l_{\text {orgI }}\right)$, organically bound $\left(\mathrm{Al}_{\text {org }}\right)$, bioavailable $\left(\mathrm{Al}_{\text {bio }}\right)$ and total $\left(\mathrm{Al}_{\text {tot }}\right)$, which were then assayed by speciation analysis (Fig. 1). The notation was as follows:

$$
\begin{array}{ll}
\mathrm{Al}_{\text {exch }}=\mathrm{Al}_{\mathrm{BaCl} 2} & \mathrm{Al}_{\text {orgI }}=\mathrm{Al}_{\mathrm{CuCl} 2}-\mathrm{Al}_{\mathrm{BaCl} 2} \\
\mathrm{Al}_{\text {org }}=\mathrm{Al}_{\mathrm{Na} 4 \mathrm{P} 207}-\mathrm{Al}_{\mathrm{BaCl} 2} & \mathrm{Al}_{\text {bio }}=\mathrm{Al}_{\mathrm{Na} 4 \mathrm{P} 2 \mathrm{O} 7}
\end{array}
$$

Each assay was repeated at least three times. The results are given in Table 1.

\section{Results and Discussion}

The soils were strongly acidic. The $\mathrm{pH}_{\mathrm{H} 2 \mathrm{O}}$ and $\mathrm{pH}_{\mathrm{KCl}}$ in the $\mathrm{O}$ layer changed from 3.55 to 3.91 and from 2.57 to 3.39 , respectively. The higher the content of humus (which has strong sorptive properties) in the soil, the higher the difference $\Delta \mathrm{pH}=\mathrm{pH}_{\mathrm{H} 2 \mathrm{O}}-\mathrm{pH}_{\mathrm{KCl}}$. The soils collected in the Bukowiec Forest District are more acidic than in Istebna. The difference between average $\mathrm{pH}_{\mathrm{KCl}}$ values in the samples taken in Istebna and Bukowiec was statistically significant $\left(\Delta \mathrm{pH}_{\mathrm{KCl}}=0.22 F=3.45<F_{\alpha=0.01}=\right.$ 4.92, $\left.t=3.776>t_{\alpha=0.01}=2.787\right)$. The area did not reveal any marked effects of the sampling height on the changes in soil $\mathrm{pH}$. The concentrations of organic matter $w_{\text {org }}$, total carbon $\mathrm{C}_{\text {tot }}$ and nitrogen $\mathrm{N}_{\text {tot }}$ correlated strongly, which indirectly indicated a low carbonate content in the soils. The high variability in organic matter content in the soil samples (from $10 \%$ to $90 \%$ ) and $\mathrm{C}_{\text {tot }} / \mathrm{N}_{\text {tot }}[g / g]$ ratio is worth mentioning. In Bukowiec, on average, the soil contained more organic matter and was characterized

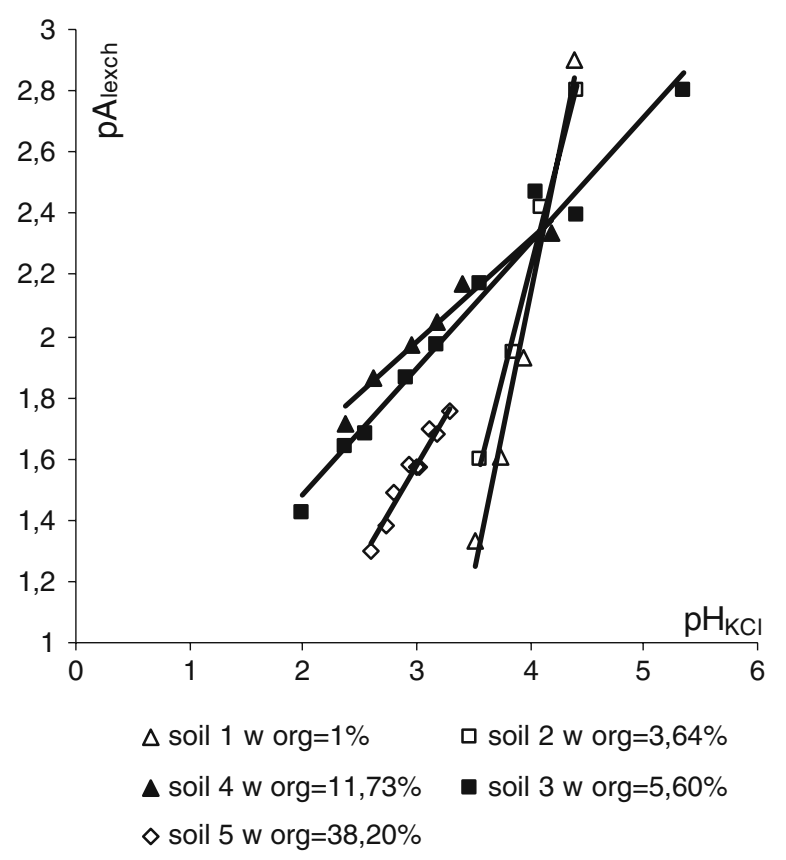

Fig. 3 Effect of $\mathrm{pH}_{\mathrm{KCl}}$ on exchangeable aluminium concentration in soil 


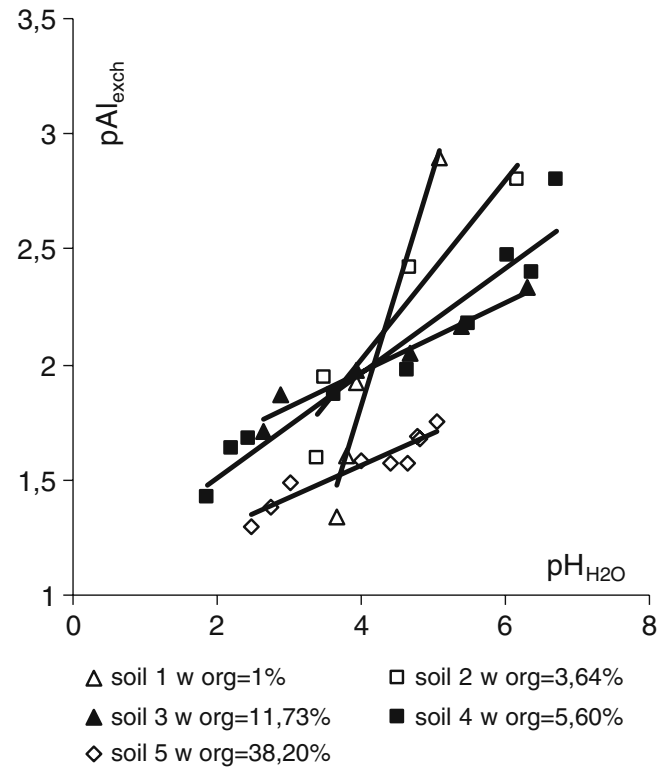

Fig. 4 Effect of $\mathrm{pH}_{\mathrm{H} 2 \mathrm{O}}$ on exchangeable aluminium concentration in soil

by a higher $\mathrm{C}_{\text {tot }} / \mathrm{N}_{\text {tot }}$ ratio. A weak negative correlation between $\mathrm{C}_{\text {tot }} / \mathrm{N}_{\text {tot }}$ and the sampling height was found (Smoliński et al. 2009). The cation exchange capacity (CEC) changed over 9.48-22.41. Obviously, the higher organic matter content implies the higher CEC. All the samples showed that aluminium content in the cation exchange complex $\left(\mathrm{Al}_{\text {exch }} /\left(\mathrm{Ca}_{\text {exch }}+\mathrm{Mg}_{\text {exch }}+\mathrm{Fe}_{\text {exch }}+\right.\right.$ $\left.\left.\mathrm{Mn}_{\text {exch }}+\mathrm{K}_{\text {exch }}+\mathrm{Al}_{\text {exch }}\right) \quad\left[\left(\mathrm{cmol}_{\mathrm{c}} \mathrm{kg}^{-1}\right) /\left(\mathrm{cmol}_{\mathrm{c}} \mathrm{kg}^{-1}\right)\right]\right)$ was higher than $50 \%$, and it exceeded $80 \%$ in a number of samples, especially those collected in Istebna.

\subsection{Exchangeable Aluminium}

The soils contained over $100 \mathrm{mgkg}^{-1}$ of exchangeable aluminium $\mathrm{Al}_{\text {exch }}$, a toxic dose to coniferous trees (Motowicka-Terelak and Stuczyński 1993). Its concentrations in soil are primarily affected by its acidity (Driscoll and Schecher 1988; Illmer et al. 2003; Simonsson 2000; van Hees et al. 2001), which was confirmed by our results (Fig. 2). An increase in soil acidity brought an exponential increase in aluminium concentration. It is interesting that the amount of exchangeable aluminium in the forest soil at the same $\mathrm{pH}$ was smaller in the samples collected in Bukowiec than Istebna. The difference is better seen for $\mathrm{Al}_{\text {exch }}=f$ $\left(\mathrm{pH}_{\mathrm{KCl}}\right)$. It seems that in the soils collected in Bukowiec, the negative effect of acidity was reduced by the sorptive properties of organic matter or the formation of aluminium ion complexes by organic matter (organic acids; Kotowski et al. 1995).

Among other authors, the effect of organic matter on exchangeable aluminium concentrations in soil has been emphasized by: Thomas (1976); Bloom et al. (1979); Lundstrom (1993); Wesselink and Mulder (1995); de Wit et al. (1999); Berggren and Muller (1995) and Mulder et al. (2001). Since it was impossible to select soil samples of different $\mathrm{pH}$ and constant humus content, an additional series of tests was carried out. Five soil samples which markedly differed in organic matter concentrations were collected from different layers of the soil profile. After they had been dried at room temperature, the samples were sieved through a 2-mm sieve and $\mathrm{pH}_{\mathrm{KCl}}, \mathrm{pH}_{\mathrm{H} 2 \mathrm{O}}$ and weight percentage of organic matter $w_{\text {org }}[\%]$ were determined in each one. Then, each sample was divided into five to nine 200-g sub-samples and placed in quartz beakers, adding either $90 \mathrm{ml}$ of $0.1 \div 0.5 \mathrm{M}$ nitric(V) acid solution (alternatively $0.1 \div 0.5 \mathrm{M}$ sulfuric(VI) acid), $0.1 \div 1.0 \mathrm{M}$ potassium hydroxide or distilled water. The beakers were covered with watch glasses and stored in the dark at room temperature. The content of the

Table $3 \mathrm{pAl}_{\text {exch }}=-\log \left(\mathrm{Al}_{\mathrm{exch})}=f(\mathrm{pH})\right.$ trends (soil samples $\left.1-5\right)$

\begin{tabular}{|c|c|c|c|c|c|c|c|}
\hline \multirow[t]{2}{*}{ Soil sample no. } & \multirow[t]{2}{*}{$w_{\text {org }}(\%)$} & \multicolumn{3}{|c|}{$\begin{array}{l}\text { Equation of a trend line } \\
\mathrm{pAl}_{\text {exch }}=-\log \left(\mathrm{Al}_{\mathrm{exch}}\right)=\boldsymbol{\alpha} \mathrm{pH}_{\mathrm{KCl}}+\boldsymbol{\beta}\end{array}$} & \multicolumn{3}{|c|}{$\begin{array}{l}\text { Equation of a trend line } \\
\mathrm{pA} 1_{\mathrm{exch}}=-\log \left(\mathrm{Al}_{\mathrm{exch})}=\boldsymbol{A} \mathrm{p}_{\mathrm{H} 2 \mathrm{O}}+\boldsymbol{B}\right.\end{array}$} \\
\hline & & $\alpha$ & $\beta$ & $R^{2}$ & $A$ & $B$ & $R^{2}$ \\
\hline 1 & 1.00 & 1.8805 & -5.2666 & 0.9831 & 1.0194 & -2.2460 & 0.9631 \\
\hline 2 & 3.64 & 1.4708 & -3.6566 & 0.9909 & 0.3908 & 0.4555 & 0.9138 \\
\hline 3 & 5.60 & 0.4116 & 0.6566 & 0.9770 & 0.2279 & 1.0483 & 0.9302 \\
\hline 4 & 11.73 & 0.3375 & 0.9648 & 0.9656 & 0.1501 & 1.3700 & 0.9676 \\
\hline 5 & 38.20 & 0.6574 & -0.3890 & 0.9572 & 0.1418 & 0.9921 & 0.8911 \\
\hline
\end{tabular}


Table 4 Extraction of soil samples $1-5$ with $10 \%$ $\mathrm{HNO}_{3}$

\begin{tabular}{lrlllllr}
\hline Soil sample & $\mathrm{w}_{\text {org }}, \%$ & $\begin{array}{l}\mathrm{K}, \\
\mathrm{mgkg}^{-1}\end{array}$ & $\begin{array}{l}\mathrm{Ca}, \\
\mathrm{mgkg}^{-1}\end{array}$ & $\begin{array}{l}\mathrm{Mg}, \\
\mathrm{mgkg}^{-1}\end{array}$ & $\begin{array}{l}\mathrm{Fe}, \\
\mathrm{mgkg}^{-1}\end{array}$ & $\begin{array}{l}\mathrm{Mn}, \\
\mathrm{mgkg}^{-1}\end{array}$ & $\begin{array}{l}\mathrm{Zn}_{\mathrm{mgkg}^{-1}} \\
1\end{array}$ \\
\hline 1.00 & 14 & 40 & 6.1 & 499 & 5.1 & 5.6 \\
2 & 3.64 & 16 & 49 & 4.8 & 1,236 & 1.0 & 5.4 \\
3 & 5.60 & 961 & 75 & 7.4 & 81 & 0.4 & 6.4 \\
5 & 11.73 & 911 & 119 & 13 & 879 & 1.1 & 9.6 \\
\hline
\end{tabular}

beakers was occasionally wetted with distilled water and mixed. After 3 months, the sub-samples were dried at room temperature, sieved and then $\mathrm{pH}_{\mathrm{HCl}}, \mathrm{pH}_{\mathrm{H} 2 \mathrm{O}}$ and exchangeable aluminium concentrations $\mathrm{Al}_{\text {exch }}$ were assayed again. Each assay was repeated three times. The averaged results are given in Table 2 and Figs. 3 and 4.

Figure 3 shows $\mathrm{pAl} 1_{\mathrm{exch}}=f\left(\mathrm{pH}_{\mathrm{KCl}}\right)$ trend lines for all five soil samples (exchangeable aluminium concentration was expressed in $\mathrm{mmolg}^{-1}$ ) and their correlation coefficients $R^{2}$ are shown in Table 3. A group of trend lines formed crossed at $\mathrm{pH}_{\mathrm{KCl}} \approx 4.10, \mathrm{Al}_{\text {exch }} \approx 110 \mathrm{mgkg}^{-1}$. The inclination coefficient of the $\alpha$ trend lines for the first four soil samples decreased-the amount of exchangeable aluminium was smaller in the soils of the same acidity and higher content of humus. Humus reduced the negative effects of soil acidity. In sample number five, which was characteristic of the highest organic matter content, the $\boldsymbol{\alpha}$ coefficient of the trend line was higher than in samples 3 and 4.

If soil acidity is expressed as $\mathrm{pH}_{\mathrm{H} 2 \mathrm{O}}$ measured in water, the position of trend lines $\mathrm{pAl}_{\mathrm{exch}}=f\left(\mathrm{pH}_{\mathrm{H} 2 \mathrm{O}}\right)$ is slightly different (Fig. 4). The inclination coefficient of $\boldsymbol{A}$ trend lines decreased for the samples with increasing humus content in the soil and the $\boldsymbol{A}$ coefficient for sample 5 was the lowest (Table 3). However, compared to other trends, this one was shifted towards the higher exchangeable aluminium concentrations in the soil.

This indicates that another additional factor decides about the concentration of exchangeable aluminium in the soil in this case. It might be the presence of cations which compete with aluminium in the formation of organic complexes in the soil. Therefore, the extraction of the five soil samples with $10 \%$ nitric acid was carried out, followed by assays of potassium, calcium, magnesium, manganese, zinc and iron in the extract $(10 \%$ nitric acid is used for extracting soil in order to estimate the number of metal forms that can enter the food chain (Ostrowska et al. 1991)). It has been found that the soils differed in the amount of extracted iron, manganese, potassium, calcium and magnesium (Table 4). Only zinc concentrations were similar in samples 1-4 and considerably higher in sample 5 characterized by the highest organic matter content. Potassium, calcium and magnesium concentrations correlated positively with organic matter content. Iron concentration did not correlate with the humus content. It seems that, apart from the content of organic matter, the $\alpha$ coefficient of trend lines $\mathrm{pAl}_{\mathrm{ech}}=f\left(\mathrm{pH}_{\mathrm{KCl}}\right)$
Fig. 5 Effect of exchangeable calcium and magnesium on exchangeable aluminium content in the surface O layer of soil
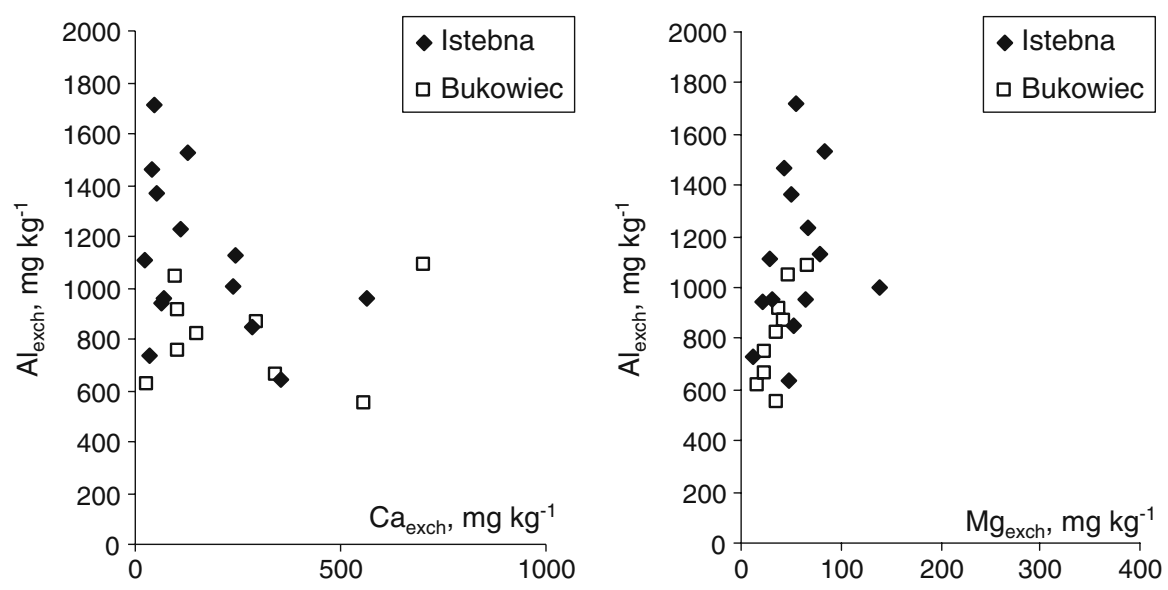


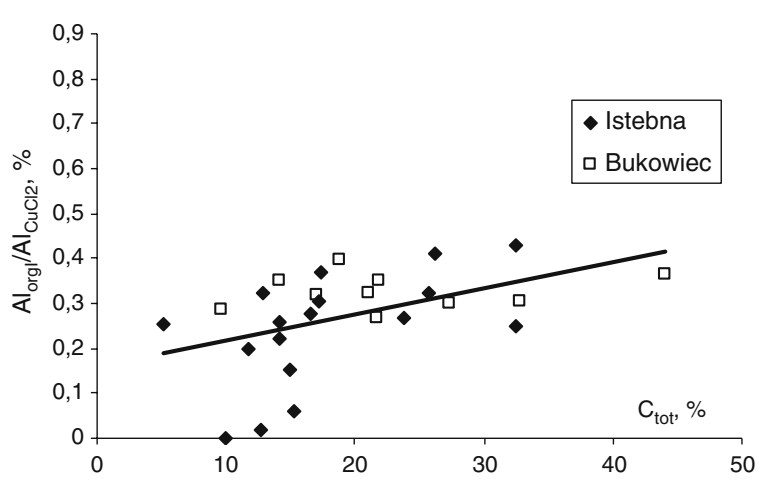

Fig. 6 Effect of total carbon $\mathrm{C}_{\text {tot }}$ on the weakly organically bound aluminium fraction $\mathrm{Al}_{\text {orgI }}$ in the total amount of aluminium leached with copper(II) chloride solution

was also affected by exchangeable iron and calcium concentrations in soils samples $1-5$. The conclusion needs to be confirmed by further research.

Other parameters that greatly affected aluminium $\mathrm{Al}_{\text {exch }}$ content in the soils in Istebna and Bukowiec include exchangeable calcium and magnesium concentrations. The larger the amount of calcium $\mathrm{Ca}_{\text {exch }}$ and magnesium $\mathrm{Mg}_{\text {exch }}$, the smaller the amount of exchangeable aluminium in the surface layer of the soil. The correlation is indirectly connected with the effect of $\mathrm{pH}$ - the higher soil acidity, the smaller amount of exchangeable basic cations (Fig. 5). Ca/Al and $\mathrm{Mg} / \mathrm{Al}$ molar ratios are used as an indicator of aluminium toxicity in soil (Urlich et al. 1980).

\subsection{Weakly Organically Bound and Bioavailable Aluminium}

Copper displaces aluminium in organic complexes; therefore, the assays of $\mathrm{Al}_{\text {orgI }}$ fraction for soil extraction make use of $0.5 \mathrm{M}$ solution of its chloride. The fraction is a sum of the exchangeable and weakly organically bound forms. The effect of $\mathrm{pH}$ on aluminium $\mathrm{Al}_{\mathrm{CuCl} 2}$ concentration is very similar to the effect of acidity on $\mathrm{Al}_{\text {exch. }}$. The influence of the other parameters is ambiguous. The concentration of weakly organically bound aluminium ranges from several to $650 \mathrm{mg} \mathrm{kg}^{-1}$. Average values for the samples collected in Istebna and Bukowiec were similar (Table 1). The wide scatter of the results may be caused by the fact that the amount of aluminium $\mathrm{Al}_{\text {orgI }}$ is calculated from the difference of experimentally measured values of $\mathrm{Al}_{\mathrm{CuCl} 2}$ and $\mathrm{Al}_{\text {exch }}$. Figure 6 demonstrates the effect of organic matter on the percentage of weakly organically bound $\mathrm{Al}_{\text {orgI }}$ in the total amount of aluminium extracted with copper(II) chloride $\left(\mathrm{Al}_{\text {orgI }} / \mathrm{Al}_{\mathrm{CuCl} 2}\right)$. The ratio of $\mathrm{Al}_{\text {orgI }} / \mathrm{Al}_{\mathrm{CuCl} 2}$ fell within $0.2-0.4$. It was lower than 0.1 for three points. As it can be seen, the ratio $\mathrm{Al}_{\text {orgl }} /$ $\mathrm{Al}_{\mathrm{CuCl} 2}$ considerably increased with increasing humus content in the soil.

The fraction of bioavailable aluminium $\mathrm{Al}_{\text {bio }}$ is a sum of exchangeable $\mathrm{Al}_{\text {exch }}$ and organic $\mathrm{Al}_{\text {org }}$ aluminium. The assays of the bioavailable fraction pose problems, since sodium diphosphate(V) solution can leach part of amorphous aluminium as well (Walna et al. 2005). Bertsch and Bloom (1996) emphasize that extraction should be carried out with a solution of constant $\mathrm{pH}$ and the final results are affected by the time of aluminium assays in eluates.

The percentages of exchangeable and organic aluminium in the total content of bioavailable aluminium were calculated in the soil samples collected in Bukowiec, where humus content ranged widely (Table 1). The increasing concentration of
Fig. 7 Effect of organic matter on the exchangeable and organically bound aluminium fractions in the total amount of mobile aluminium (Bukowiec series)

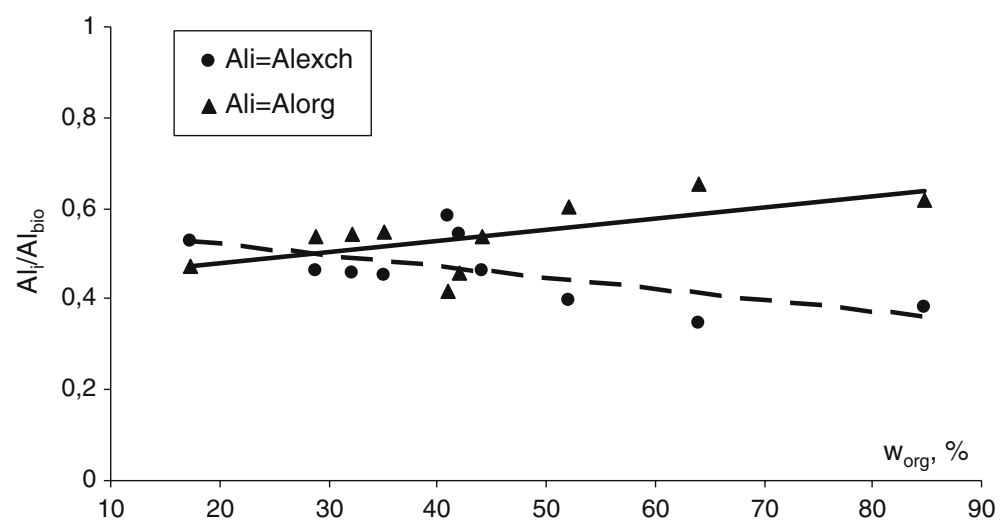




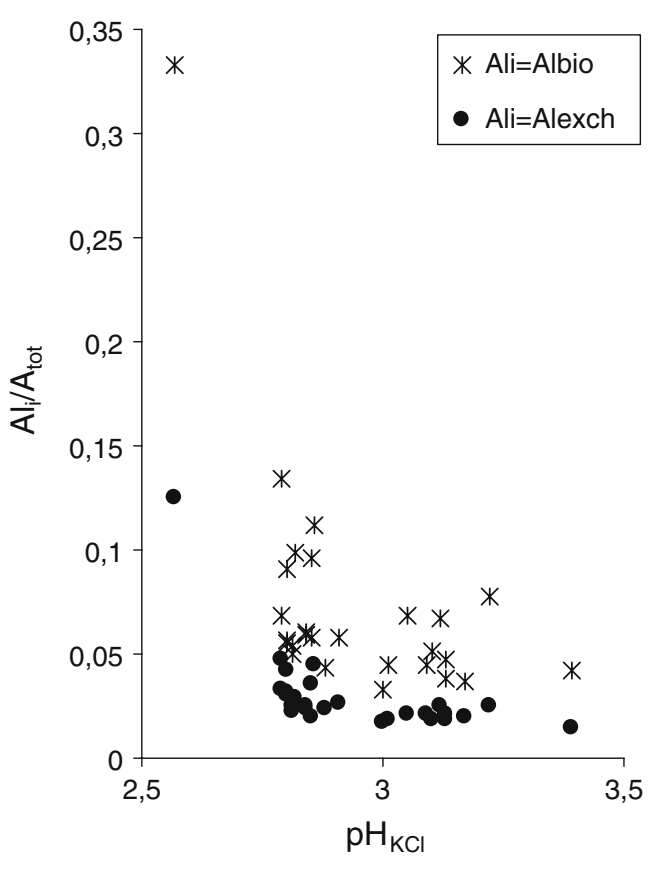

Fig. 8 Effect of $\mathrm{pH}_{\mathrm{KCl}}$ on the amount of bioavailable and exchangeable aluminium in the total concentration of aluminium in soil

organic matter in the soil brought about an increase in aluminium content in the organic fraction, less dangerous to plants, and its decrease in the phytotoxic exchangeable fraction (Fig. 7).

Total aluminium was also assayed in the soil samples, digesting them with hydrofluoric acid. Total aluminium concentration ranged widely (Table 1) and correlated with organic matter concentration. The metal, being one of the basic components of soil, is bound primarily in sparingly soluble aluminosilicates. The more organic matter and less mineral fractions in the soil, the more aluminium assayed in the samples.

The amount of the bioavailable $\mathrm{Al}_{\text {bio }} / \mathrm{Al}_{\text {tot }}$ and exchangeable aluminium $\mathrm{Al}_{\text {exch }} / \mathrm{Al}_{\text {tot }}$ fractions in the total aluminium content in the soil were on average 0.09 and 0.03 , respectively. Increasing $\mathrm{pH}$ decreased the content of exchangeable and bioavailable aluminium in the soil (Fig. 8).

\subsection{Assays of Soil Samples Collected in the Areas Free of Degradation}

Three reference samples were taken for comparison: two in the Poprad Landscape Park, the Sadecki Beskids (the Western Carpathians) and one in Koszęcin (Silesia). The areas do not experience the pandemic dying of spruce trees.

The Sadecki Beskids are part of the Western Carpathians composed of flysch of Magura nappe. They are densely covered with spruce and beech trees. Koszęcin is located in the so called White Silesia, Lubliniec Land, in the north-west part of Silesian-Kraków Upland. The ground is composed of limestone and sandstone.

The assays focused on the selected parameters only. The results are given in Table 5 and show that the concentration of exchangeable aluminium in the reference soil was much lower. The good condition of the forests in the Saqdecki Beskids is particularly satisfying. Both samples revealed much lower acidity than that in the soil collected in the Silesian Beskids. The exchangeable complex is predominant with calcium and magnesium (approximately $80 \%$ of CEC), and aluminium content reached $20 \%$ of CEC. Slightly worse parameters were found in the $\mathrm{O}$ soil layer collected in Koszęcin. The higher acidity and lower $\mathrm{Ca}_{\text {exch }}$ and $\mathrm{Mg}_{\text {exch }}$ content may be also caused by the proximity of the zinc plant in Miasteczko Śląskie.

\section{Conclusions}

The choice of the sampling site in the Barania Gora range resulted from the condition of the forest. The difference between the mean $\mathrm{pH}_{\mathrm{KCl}}$ values in the

Table 5 Characteristics of soil collected at reference sites

\begin{tabular}{|c|c|c|c|c|c|c|c|c|c|c|c|}
\hline Parameter & $\mathrm{pH}_{\mathrm{KCl}}$ & $\mathrm{C}_{\text {org }}$ & $\begin{array}{l}\mathrm{Ca}_{\text {exch }} \\
\left(\mathrm{mgkg}^{-1}\right)\end{array}$ & $\begin{array}{l}\mathrm{Mg}_{\text {exch }} \\
\left(\mathrm{mgkg}^{-1}\right)\end{array}$ & $\begin{array}{l}\mathrm{Fe}_{\text {exch }} \\
\left(\mathrm{mgkg}^{-1}\right)\end{array}$ & $\begin{array}{l}\mathrm{Mn}_{\text {exch }} \\
\left(\mathrm{mgkg}^{-1}\right)\end{array}$ & $\begin{array}{l}\mathrm{CEC} \mathrm{cmol}_{\mathrm{c}} \\
\left(\mathrm{kg}^{-1}\right)\end{array}$ & $\begin{array}{l}\mathrm{Al}_{\text {exch }} \\
\left(\mathrm{mgkg}^{-1}\right)\end{array}$ & $\begin{array}{l}\mathrm{Al}_{\text {orgI }} \\
\left(\mathrm{mgkg}^{-1}\right)\end{array}$ & $\begin{array}{l}\mathrm{Al}_{\text {org }} \\
\left(\mathrm{mgkg}^{-1}\right)\end{array}$ & $\begin{array}{l}\mathrm{Al}_{\text {bio }} \\
\left(\mathrm{mgkg}^{-1}\right)\end{array}$ \\
\hline Poprad 1 & 3.96 & 9.1 & 2,832 & 221 & 16 & 172 & 12.52 & 178 & 358 & 837 & 1,015 \\
\hline Poprad 2 & 3.60 & 33.3 & 4,967 & 287 & 19 & 470 & 14.00 & 67 & 187 & 497 & 564 \\
\hline Koszęcin & 3.19 & 7.7 & 404 & 32 & 88 & 8 & 8.42 & 326 & 93 & 1,374 & 1,700 \\
\hline
\end{tabular}


samples taken in Istebna (area of cut down spruce forest) and Bukowiec (area of healthy spruce forest) is statistically significant. The average content of exchangeable aluminium hazardous to coniferous trees was much higher than permissible standards in both areas, being approximately $1,090 \mathrm{mgkg}^{-1}$ in Istebna (despite the lower acidity of the soil) and was about $300 \mathrm{mgkg}^{-1}$ higher than in Bukowiec. It was probably caused by the lower content of organic matter and smaller amount of calcium in the exchangeable complex in the samples taken in Istebna. Those soils also revealed a higher content of bioavailable aluminium forms. The average CEC was similar for both. The exchangeable complex in the soil of the forest in Istebna contained $84 \%$ of aluminium and $9 \%$ of total calcium and magnesium on average. In Bukowiec, the percentage of aluminium in CEC was slightly lower and reached $78 \%$ while the value for total calcium and magnesium was $14 \%$.

Various factors were taken into consideration as the causes of spruce stand deterioration in the Silesian Beskids: industrial contamination, diseases caused by fungi (armillaria), insect pests, genetically different origin of the stands (Conference Materials 2006). The results indicate that the chemical changes brought about by acid rain were the direct cause. The strongly acidic soils of the Silesian Beskids caused considerable solubilization of aluminium, its increase in the soil solution and finally resulting in its toxic properties. The significant decrease in calcium and magnesium content in the sorptive complex of the soil reduced the vitality of spruce trees vulnerable to aluminium effects and their general resistance to diseases. This means withering for young trees and for older ones, the thinning of the crown, brittle cellulose fibres, lack of resistance to abnormal weather conditions, invasions of insects or parasitic fungi, i.e., all the phenomena observed in the Silesian Beskids.

Unfortunately, there is a possibility that the areas where trees have not been withering so far might face the deterioration in the condition of spruce forests. This is indirectly indicated by our analysis of the soil in Bukowiec, the Barania Góra range. Despite the positive assessment of the forest condition made by foresters during the sampling period, the ongoing chemical changes in the soil affected adversely the condition of the trees. The following years the areas adjacent to the experimental plot experienced wind- throw and recently, the situation deteriorated noticeably, which necessitated sanitation felling in some parts of the forest.

Open Access This article is distributed under the terms of the Creative Commons Attribution Noncommercial License which permits any noncommercial use, distribution, and reproduction in any medium, provided the original author(s) and source are credited.

\section{References}

Berggren, D., \& Muller, J. (1995). The role of organic master in controlling aluminium solubility in acidic mineral horizons. Geochimica and Cosmochimica Acta, 59, 4167-4180.

Bertsch, P. M., \& Bloom, P. R. (1996). Aluminum. In J. M. Bartels (Ed.), Methods of soil analysis. Soil science society of America and American society of agronomy. Part 3. Chemical methods (pp. 517-550). Madison, USA: Soil Science Society of America, Inc.

Bloom, P. R., McBridge, M. B., \& Weaver, R. M. (1979). Aluminium organic matter in acid soil: buffering and solution aluminium activity. Soil Science Society of American Journal, 43, 488-493.

Borůvka, L., Mládkowá, L., \& Drábek, O. (2005a). Factors controlling spatial distribution of soil acidification and $\mathrm{Al}$ forms in forest soils. Inorganic Biochemistry, 99, 1796-1806.

Borůvka, L., Mládkowá, L., Drábek, O., \& Vašát, R. (2005b). Factors of spatial distribution of forest floor properties in the Jizerske Mountains. Plant Soil and Environment, 51 (10), 447-455.

Borůvka, L., Podrázsky, V., Mládková, L., Keneš, I., \& Drabek, O. (2005c). Some approaches to the research of forest soils affected by acidification in the Czech Republic. Soil Science \& Plant Nutrition, 51(5), 745-749.

de Wit, H. A., Kotowski, M., \& Mulder, J. (1999). Modelling aluminium and organic matter solubility in the forest floor using WHAM. Soil Science Society of American Journal, 63, 1141-1148.

Drábek, O., Borůvka, L., Mládková, L., \& Kocarek, M. (2003). Possible method of aluminium speciation in forest soils. Journal of Inorganic Biochemistry, 97, 8-15.

Driscoll, C. T., \& Schecher, W. D. (1988). Aluminum in environment. In A. Sigel (Ed.), Metal ions in biological systems, Vol. 24, Aluminum and its role in biology (pp. 59122). New York: Marcel Dekker.

"Hazards to the life of forests in the Beskids, causes and prevention" (in Polish) Ustroń-Jaszowiec, 23-24 November 2006, Conference Materials.

Illmer, P., Obertegger, U., \& Schinner, F. (2003). Microbiological properties in acidic forest soils with special cosideration of $\mathrm{KCl}$ extractable Al. Water, Air and Soil Pollution, 148, 3-14.

Kotowski, M., Wieteska, E., Pawłowski, L. \& Kozak, Z. (1994). Characteristics of different aluminium forms occurrence in selected environmental elements in Poland 
(in Polish) Państwowa Inspekcja Ochrony Środowiska, Warszawa.

Kotowski, M., Pawłowski, L., \& Zhu, X. (1995). Aluminium in the environment (in Polish) Wydawnictwo Politechniki Lubelskiej, Lublin.

Lundstrom, U. S. (1993). The role of organic acids in the soil solution chemistry of a podzolized soil. Journal of Soil Science, 44, 121-133.

Mládková, L., Borůvka, L., Drábek, O., \& Vasat, R. (2006). Factors influencing distribution of different $\mathrm{Al}$ forms in forest soils of the Jizerskè hory Mts. Journal of Forest Science, 52(Special Issue), 87-92.

Mládkowá, L., Borůvka, L., \& Drábek, O. (2004). Distribution of labile aluminium forms in soils of Jizera Mountains region. Plant Soil and Environment, 50, 46-351.

Motowicka-Terelak, T. \& Stuczyński, T. (1993). Effect chemical contaminants on aluminium in soils. Chromium, nickel and aluminium in the environment - ecological and methodological problems. (in Polish). Ossolineum.

Mulder, J., de Wit, H. A., Boonen, H. W. J., \& Bakken, L. R. (2001). Increased levels of aluminium in forest soils: effects on the stores of soil organic carbon. Water Air and Soil Pollution, 130, 989-994.

Musil, I., \& Pavliček, V. (2002). Liming of forest soils: effectiveness of particle size fractions. Journal of Forest Science, 48, 121-129.

Ostrowska, A., Gawliński, St., \& Szczubiałka, Z. (1991). Methods for analyzing and assessing the properties of soil and plants. (in Polish) Instytut Ochrony Środowiska, Warszawa.

Polish Standard PN-ISO 11260:1999 Soil quality-determination of effective cation exchange capacity and base saturation degree, using barium chloride solution. (in Polish).
Simonsson, M. (2000). Interactions of aluminium and fulvic acid in moderately acid solutions: stoichiometry of the $\mathrm{H}^{+} / \mathrm{Al}^{3+}$ exchange. European Journal of Soil Science, 51, 655-666.

Smal, H., \& Misztal, M. (1996). Soil solution chemistry in the profiles of forest and arable light textured soils, SE Poland. Applied Geochemistry, 11(1), 81-85.

Smoliński, A., Zołotajkin, M., Ciba, J., Dydo, P., \& Kluczka, J. (2009). PLS-EP algorithm to predict aluminium content in soils of Beskid Mountains region. Chemosphere, 76, 565571.

Staszewski, T. (2004). Reaction of spruce stands to the deposition of air contaminants. (in Polish). Wydawnictwo Uniwersytetu Śląskiego, Katowice.

Thomas, G. W. (1976). The relationship between organic matter content and exchangeable aluminium in acid soils. Soil Science Society of American Journal, 39, 591.

Urlich, B. R., Mayer, C., \& Khanna, P. K. (1980). Chemical changes to acid precipitation in loess derived soil in central Europe. Soil Science, 130, 193-199.

van Hees, P., Lundstöm, U., Danielsson, R., \& Nyberg, L. (2001). Controlling mechanisms of aluminium in soil solution-an evaluation of 180 podzolic forest soils. Chemosphere, 45, 1091-1101.

Walna, B., Spychalski, W., \& Siepak, J. (2005). Assessment of potentially reactive pools of aluminium in poor forest soils using two methods of fractionation analysis. Journal of Inorganic Biochemistry, 99, 1807-1816.

Wesselink, L., \& Mulder, J. (1995). Modelling Al-solubility controls in an acid forest soil, Solling, Germany. Ecological Modelling, 83, 109-117. 